\title{
Parasites of non-native freshwater fishes introduced into England and Wales suggest enemy release and parasite acquisition
}

\author{
Danny J. Sheath · Chris F. Williams • \\ Amy J. Reading $\cdot$ J. Robert Britton
}

Received: 18 March 2014 / Accepted: 24 February 2015/Published online: 24 June 2015

(C) The Author(s) 2015. This article is published with open access at Springerlink.com

\begin{abstract}
When non-native species are introduced into a new range, their parasites can also be introduced, with these potentially spilling-over into native hosts. However, in general, evidence suggests that a high proportion of their native parasites are lost during introduction and infections by some new parasites from the native range might occur, potentially resulting in parasite spill-back to native species. These processes were investigated here using parasite surveys and literature review on seven non-native freshwater fishes introduced into England and Wales. Comparison of the mean numbers of parasite species and genera per population for each fish species England and Wales with their native ranges revealed $<9 \%$ of the native parasite fauna were present in their populations in England and Wales. There was no evidence suggesting these introduced parasites had spilled over into sympatric native fishes. The non-native fishes did acquire parasites
\end{abstract}

Electronic supplementary material The online version of this article (doi:10.1007/s10530-015-0857-8) contains supplementary material, which is available to authorized users.

D. J. Sheath $(\bowtie) \cdot$ J. R. Britton

Centre for Ecology, Environmental and Sustainability, Department of Life and Environmental Sciences, Faculty of Science and Technology, Bournemouth University, Poole BH12 5BB, UK

e-mail: dsheath@bournemouth.ac.uk

C. F. Williams · A. J. Reading

Environment Agency, Fisheries Technical Services,

Brampton, Huntingdon, Cambridgeshire, UK following their introduction, providing potential for parasite spill-back to sympatric fishes, and resulted in non-significant differences in overall mean numbers of parasites per populations between the two ranges. Through this acquisition, the non-native fishes also had mean numbers of parasite species and genera per population that were not significantly different to sympatric native fishes. Thus, the non-native fishes in England and Wales showed evidence of enemy release, acquired new parasites following introduction providing potential for spill-back, but showed no evidence of parasite spill-over.

Keywords Pathogen - Invasive species $\cdot$ Non-native fish $\cdot$ Freshwater ecosystems

\section{Introduction}

Introductions of non-native species raise concerns over the impacts they can have on native biodiversity, including predation pressure, increased competition and disruptions to ecosystem functioning (Hulme et al. 2009; Pysek et al. 2010). When free-living species are introduced then their parasite fauna can also be introduced (Williams et al. 2013). These parasites then potentially spill-over into native species, with the potential that resistance and tolerance of these new hosts to infection will be low (Torchin et al. 2003; Kelly et al. 2009). Both lethal and sub-lethal host consequences might be incurred, with the latter 
including pathological, physiological, and/or behavioural changes, with likely adverse consequences for growth, survival, and fitness (Tompkins et al. 2001; Hewlett et al. 2009; Britton 2013). Notwithstanding, the introduction process might filter out many of these parasites through, for example, only a small sub-set of free-living individuals of low parasite diversity being removed from the native range and/or their parasites having high host specificity, with these hosts absent in the new range (Torchin et al. 2003). Of those parasites that are introduced, their consequences for the receiving ecosystem will vary according to factors including the complexity of their lifecycle, their ability to spillover to native species, and the extent of the natural resistance and resilience to infection in these new hosts (Kelly et al. 2009).

Interactions between introduced species and parasites have raised a number of hypotheses in invasion biology. The 'Enemy Release Hypothesis' predicts that the parasite loss experienced by non-native species will enhance their ability to establish and invade (Keane and Crawley 2002; Mitchell and Power 2003; Hatcher and Dunn 2011). Torchin and Mitchell (2004) suggested that when a species is introduced, it escapes at least $75 \%$ of their parasites from their native range and thus will gain substantial benefits regarding their fitness and survival in the invasive range (Torchin et al. 2003). The enemy release hypothesis has been used as the basis to explain the invasion success of a diverse range of species, including non-native slugs (Ross et al. 2010), mosquitoes (Aliabadi and Juliano 2002) and frogs (Marr et al. 2008). In fish, for two introduced fish species (Apollonia melanostoma and Proterorhinus semilunaris) in the North American Great Lakes, parasite diversity in both species was considerably lower than their native range, despite them also being present for approximately 100 years (Kvach and Stephien 2008). Many relevant studies have focused on invasive plants that show enemy release processes (e.g. Keane and Crawley 2002; Mitchell and Power 2003; Liu and Stiling 2006), but support is also present in other taxa, including fish (e.g. Poulin and Mouillot 2003). The 'Parasite spill-over' (PSO) hypothesis suggests that those parasites that have been introduced might now 'spill-over' to native species (Prenter et al. 2004; Kelly et al. 2009; Britton 2013). This is a concern as the lack of co-evolution between the parasite and its new host potentially results in low resistance and resilience to infection (Taraschewski 2006). In addition, some native parasites might be transmitted from the native species to the non-native species; if the non-native species is a competent host that acts a reservoir of infection, it can result in parasite spillback (PSB) to native species, increasing their disease impacts at individual and population levels (Kelly et al. 2009).

An issue with these hypotheses in non-plant taxa relates to the lack of empirical data available for the parasite fauna of many introduced species. Consequently, the aim here was to use these hypotheses as the basis for investigating the parasite fauna of nonnative freshwater fish and the native freshwater fish communities in which they reside. The rationale for using freshwaters was that drainage basins tend to act as biogeographic islands and thus present obstacles to natural fish migration (and so barriers to their parasites also) between basins (Gozlan et al. 2010a, b). The study area was England and Wales, hereafter referred to as the "introduced range". The study objectives were to: (1) compare the diversity and characteristics (internal/external attachment; specialist/generalist) of the parasite fauna of non-native fishes between freshwaters in the introduced range and their native ranges; and (2) assess the diversity and characteristics of parasites in non-native fish populations in the introduced range and compare them to the diversity and characteristics of the parasites present in the native fish of the host communities. Specialist parasites were those where their literature suggested very high host specificity, whereas generalists were those of lower host specificity. These outputs were then discussed in relation to enemy release, parasite spillover and parasite spillback processes.

\section{Methods}

Non-native fish species

The non-native fish present in the introduced range that were used in the study were European catfish Silurus glanis, pumpkinseed Lepomis gibbosus, topmouth gudgeon Pseudorasbora parva, sunbleak Leucaspius delineatus, black bullhead Ameiurus melas, bitterling Rhodeus amarus and fathead minnow Pimephlaes promelas. The justification for their use was that data on their parasite fauna were available for at least one population and these species are not used in aquaculture in England and Wales and so any fish 
present in the wild were unlikely to have been previously exposed to any anti-parasite treatments (Table 1). In general, their distributions in England and Wales are very restricted due to fish movement legislation and regulations; indeed, the A. melas and $P$. promelas populations used in the study were the only populations present in the countries and both have since been eradicated. By contrast, the following non-native fishes were omitted from the study to avoid confounding issues with their heavy use in aquaculture would have potentially exposed them to a range of anti-parasite treatments: common carp Cyprinus carpio, goldfish Carassius auratus, rainbow trout $\mathrm{On}^{-}$ corhynchus mykiss and ide Leuciscus idus. Indeed, should any of these species be sampled in the wild in

Table 1 Number of studies, and species and genera of parasites recorded in the native range of the non-native fishes, the number of these native parasites recorded in the
England and Wales then there is high probability they originated from a fish-farm as there are, for example, few naturally recruiting populations of $C$. carpio and O. mykiss present (Fausch 2007; Britton et al. 2010). In addition, the regulations on their releases into the wild in the countries are comparatively light compared with the species included in this study, with regulations concerning $C$. carpio and $O$. mykiss broadly similar to some native fishes.

\section{Data collection}

The data on the parasite fauna of the selected nonnative fish were collated from two sources. Firstly, data on the parasite fauna of the non-native fish in

'Introduced' range (England and Wales), and the characteristics of these parasite species in both ranges (site of attachment and host specificity)

\begin{tabular}{|c|c|c|c|c|c|c|c|c|c|}
\hline \multirow[t]{2}{*}{ Species } & \multirow[t]{2}{*}{ Range } & \multirow[t]{2}{*}{ Studies } & \multirow{2}{*}{$\begin{array}{l}\text { Native } \\
\text { genera }\end{array}$} & \multirow{2}{*}{$\begin{array}{l}\text { Native } \\
\text { species }\end{array}$} & \multicolumn{4}{|c|}{ Parasite species characteristics (\%) } & \multirow[t]{2}{*}{ References } \\
\hline & & & & & Internal & External & Specialist & Generalist & \\
\hline \multirow[t]{2}{*}{ Silurus glanis } & Native & 20 & 41 & 54 & 69 & 31 & 19 & 81 & $1-8$ \\
\hline & Introduced & 6 & 6 & 6 & 50 & 50 & 17 & 83 & This study \\
\hline \multirow[t]{2}{*}{ Lepomis gibbosus } & Native & 10 & 25 & 34 & 29 & 71 & 18 & 82 & $9-19$ \\
\hline & Introduced & 1 & 3 & 3 & 0 & 100 & 0 & 100 & 20 \\
\hline \multirow{2}{*}{$\begin{array}{l}\text { Pseudorasbora } \\
\text { parva }\end{array}$} & Native & 10 & 13 & 13 & 62 & 38 & 8 & 92 & $21-22$ \\
\hline & Introduced & 4 & 1 & 0 & - & - & - & - & This study \\
\hline \multirow{2}{*}{$\begin{array}{l}\text { Leucaspius } \\
\text { delineatus }\end{array}$} & Native & 12 & 9 & 11 & 55 & 45 & 9 & 91 & $23-28$ \\
\hline & Introduced & 1 & 2 & 2 & 50 & 50 & 0 & 100 & 29 \\
\hline \multirow[t]{2}{*}{ Ameiurus melas } & Native & 25 & 12 & 15 & 80 & 20 & 20 & 80 & $30-40$ \\
\hline & Introduced & 1 & 0 & 0 & - & - & - & - & This study \\
\hline \multirow[t]{2}{*}{ Rhodeus amarus } & Native & 16 & 33 & 42 & 45 & 55 & 10 & 90 & 41 \\
\hline & Introduced & 4 & 4 & 4 & 75 & 25 & 0 & 100 & This study \\
\hline \multirow{2}{*}{$\begin{array}{c}\text { Pimephales } \\
\text { promelas }\end{array}$} & Native & 13 & 14 & 19 & 47 & 53 & 16 & 84 & $42-49$ \\
\hline & Introduced & 1 & 1 & 1 & 100 & 0 & 0 & 100 & This study \\
\hline
\end{tabular}

1 Copp et al. (2009); 2 Barzegar \& Jalali (2010); 3 Soylu (2005); 4 Mancheva et al. (2009); 5 Zdarska and Nebesarova (2005); 6 Sattari et al. (2002); 7 Roohi et al. (2014); 8 Pazooki and Masoumian (2012); 9 Hanek and Fernando (1978); 10 Esch (1971); 11 Cone and Anderson (1977a, b); 12 Rye and Baker (1984); 13 Piasecki and Falandysz (1994); 14 Hudson and Bowen (2009); 15 Grupcheva and Nedeva (2000); 16 Osborn (1911); 18 Aho et al. (1976); 18 Wilson and Ronald (1967); 19 Taylor et al. (1994); 20 Hockley et al. 2011; 21 Gozlan et al. (2010a, b); 22 Zhang et al. (2007); 23 Adrovic et al. (2011); 24 Skenderovic et al. (2011); 25 Molnar (1976); 26 Kirjušina and Vismanis (2007); 27 Davydov et al. (2003); 28 Galationov (1980); 29 Beyer et al. (2005); 30 Bangham (1941); 31 Lincicome and Van Cleave (1949); 32 Van Cleave (1921); 33 Steelman (1938); 34 Wallace (1935); 34 McAllister and Bursey (2011); 35 Seamster (1948); 36 Hugghins (1954); 37 Davidova et al. (2008); 38 Mizelle and Cronin (1943); 39 Dronen and Underwood (1980); 40 Tkach and Mills (2011); 41 Held and Peterka (1974); 42 Wilmer and Rogers (1969); 43 McDowell et al. (1992); 44 Radabaugh (1980); 45 Knipes and Janovy (2009); 46 Mitchell et al. (1982); 47 Samuel et al. (1976); 48 Merrit and Pratt (1964); 49 Voth and Larson (1968) 
freshwaters in the introduced range were collated from parasite surveys completed by the Environment Agency between 2005 and 2013 as part of their routine monitoring of wild fish populations for the presence of non-native species, parasites and diseases. With the exception of $R$. amarus from the River Great Ouse in Eastern England, the waters were all lentic sites located in lowland areas below $200 \mathrm{~m}$ altitude; their precise locations cannot be revealed due to business confidentiality reasons. The predominance of lentic sites in the study is because the study species are rarely recorded in rivers in England and Wales. After the populations were sampled by either seine netting or fish traps (method dependent on the species and habitat being sampled), the captured fish were removed from the gears, identified to species level and the non-native fish removed and transported alive to the laboratory. At the same time, samples of any native fish captured were also taken to the laboratory with the maximum sample size taken of a total of 30 native fishes in total. For this study, data were only included where the minimum sample sizes per native fish species was 10 individuals. Once at the laboratory, the fish were euthanized through an anaesthetic overdose (benzocaine solution $5 \% \mathrm{w} / \mathrm{v}$ ) and a detailed post-mortem conducted for the detection of non-native parasites, adapted from Hoole et al. (2001). Skin scrapes and internal organs were examined with aid of low and high power microscopy to enable parasite identification. Note that the data recorded in these surveys was the presence of the parasites, but not their prevalence (proportion of fish per species infected with that parasite) or parasite abundance (number or weight of parasites per fish). As such, no data were tested on parasite prevalence or abundance in subsequent analyses.

Secondly, data on the parasite fauna of the nonnative fishes in their native ranges, and supplementary data for the fishes in the introduced range, were collated from literature using searches completed in Web of Science, and supplemented by Google Scholar, using Boolean logic search terms including the host fish species and terms including all of their hosts countries (taken from www.Fishbase.org), 'parasite', 'pathogen', 'native', 'fauna', 'health check' and combinations of these. Data collated from the available papers were lists of parasites hosted by each fish species; in the majority of cases, data were not available on parasite prevalence or abundance and so are not presented here. Also, in a minority of the parasite recordings, the parasite genus was provided but not the species (e.g. Diplostomum sp.). As such, some subsequent analyses used counts of parasite number based on both species and genera; where species were used, the assumption was used that these recordings represented one species. Also, given that mxyosporidia are seldom reported in studies, their data were removed from the data set entirely to standardise the datasets for both ranges. At the conclusion of the data collection from both the laboratory work and literature reviews, further reviews were then completed for each parasite species to determine their site of attachment (i.e. whether they were internal or external parasites) and host specificity (generalist/ specialist).

\section{Data analyses}

Luque and Poulin (2007) outlined that host sample size is often an important correlate of detected parasite species richness and so the effect of study effort should be controlled in parasite richness studies to eliminate spurious sampling effects. Consequently, our data were initially tested for the relationship between study effort and parasite number (species and genera), and where this was significant then the data were corrected by dividing the number of parasite species (and genera) in each range by the number of studies or populations used to collate these data.

To compare parasite diversity between the ranges, and between the non-native fish and sympatric native fish in waters in the introduced range, the methodology was based on linear regression. To compare parasite diversity between the ranges, the first test compared the mean number of parasite species and genera per population for the non-native fishes in their native range versus the number of these parasite species and genera detected in their populations in the introduced range. The gradient of the regression line $(b)$ that described the relationship of the mean parasite species/genera per population between the ranges tested the null hypothesis that there were equal numbers of the parasite species/genera per population in both ranges. The null hypothesis was rejected when $b$ was significantly different to 1.0 and vice versa, based on its $95 \%$ confidence limits (Keith et al. 2009). The regression output also indicated if the gradient of $b$ was significantly different to zero. To then compare 
the mean number of parasites per population between both ranges, irrespective of parasite origin, the same test was used, except the data for the introduced range used the mean number of all parasite species and genera recorded per population and fish species.

The numbers of parasite species in the non-native fish and their sympatric native fish species within the invaded fish communities of the introduced range were tested using the same methodology as described. The null hypothesis was the sympatric native and nonnative fish species had equal numbers of parasites per population. In this test, genus data were not included as the species level data were largely complete. The values for the native fish were calculated for the community and as such were corrected for higher number of native fish species present versus one nonnative fish species.

To compare differences in the parasite characteristics between the ranges, the species level data were used only, as the genera data were not appropriate for identifying differences in host specificity and site of attachment. For each of the three datasets described above, the mean numbers of internal, external, specialist and generalist parasite species per population were tested between the ranges and groups using Mann-Whitney $U$ tests, as transformation did not normalise the data. All statistics were completed in SPSS v. 21.

\section{Results}

The number of parasite species and genera present in the non-native fish in their native range that were also present in these fish species in the introduced range was low, with only $8.5 \%$ of the native parasite species recorded in both ranges (Table 1). The relationship between the number of parasite species/genera and study effort was significant (species: $\mathrm{R}^{2}=0.52, \mathrm{~F}_{1,12}=12.79, P<0.01$; genera: $\mathrm{R}^{2}=0.53, \mathrm{~F}_{1,12}=13.41, P<0.01$; Table 1 ). Comparing the mean number of native parasite species and genera per population between the ranges using linear regression revealed that the gradient of both regression lines were not significantly different to zero (species: $b=0.22, \quad P=0.27$; genera: $b=0.26, \quad P=0.36$; Fig. 1a) but were significantly different to 1.0 (species: $95 \%$ confidence intervals: -0.24 to 0.67 ; genera: $95 \%$ confidence intervals -0.40 to 0.91 ; Fig. 1a), rejecting the null hypothesis. There was a significant difference in the mean number of specialist parasite species per population between the ranges (Mann-Whitney U Test: $\mathrm{Z}=-2.86$, $P<0.01$ ), but not in the mean numbers of internal, external and generalist parasite species per population (Mann-Whitney: $P>0.05$ in all cases). Of these parasites recorded in the introduced range, the following were new additions to the British freshwater fish parasite fauna (Kirk 2004): Thaparocleidus vistulensis and Ergasilus sieboldi in S. glanis (Reading et al. 2011), Onchoceleidus dispar from L. gibbosus (Hockley et al. 2011) and Ancyrocephalus pricei from A. melas. The cestode parasite Proteocephalus ocellatus was also detected in the intestinal tract of S. glanis; although it has previously been recorded in imported fish on an aquaculture site, it was thought to have been eradicated (Andrews and Chubb 1984). Its detection here suggests it might actually have established in England and Wales.

When all the parasite species and genera (irrespective of their origin) that were recorded in the nonnative fishes in both ranges were tested against study effort, the relationships were also significant (species: $\mathrm{R}^{2}=0.47, \quad \mathrm{~F}_{1,12}=10.53, \quad P<0.01 ; \quad$ genera: $\mathrm{R}^{2}=0.46, \mathrm{~F}_{1,12}=10.56, P<0.01$; Table 2). In these data, $L$. delineatus were an extreme outlier due to their high number of parasites per population in the introduced range (6.0; Table 2). Comparing the mean number of parasite species and genera per population between the ranges using linear regression revealed that with $L$. delineatus omitted as an outlier the gradients of the regression lines were not significantly different to zero (species: $b=0.21, P=0.34$; genera: ( $b=0.57, P=0.19$ ) or 1.0 (species: $95 \%$ confidence intervals: -0.81 to 1.22 ; genera: $95 \%$ confidence intervals -0.45 to 1.60 ; Fig. $1 \mathrm{~b}$ ), with this also the case for both regression lines with $L$. delineatus included $(P>0.05)$. Thus, the null hypothesis was not rejected. There were no significant differences in the mean number of internal, external, specialist or generalist parasites per population between the ranges (Mann-Whitney U Test, $P>0.05$ in all cases).

In waters in the introduced range where the nonnative fish were present, the numbers of parasite species were compared between the non-native and sympatric native fishes (Table 3 ). For L. delineatus and $P$. promelas, there were no comparative data for sympatric fish and so were omitted from the data. The relationship between population number and parasite number was significant $\left(\mathrm{R}^{2}=0.51, \mathrm{~F}_{1,8}=8.35\right.$; $P=0.02)$ and comparing the mean number of parasite 

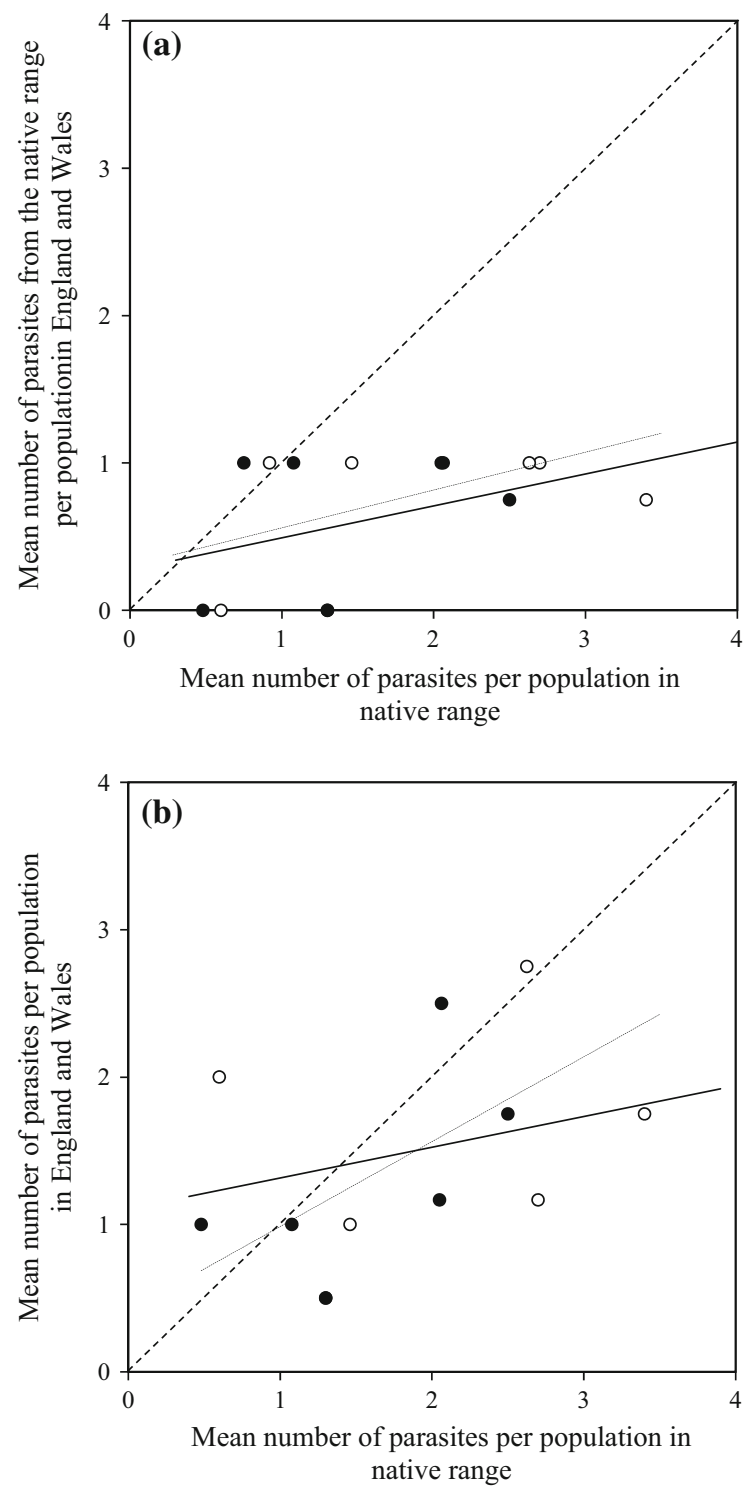

Fig. 1 a Comparison of the mean number of parasites per population in the native range of the non-native fish in Table 1 versus the mean number of these native parasites recorded per population in the introduced range, and their relationships according to linear regression (species: $\mathrm{R}^{2}=0.23, \mathrm{~F}_{1,5}=1.50$, $P>0.05)$; genus: $\left.\mathrm{R}^{2}=0.16, \mathrm{~F}_{1,5}=1.01, P>0.05\right)$. b Comparison of the mean number of parasites per population in the native range of the non-native fish in Table 1 versus their mean number of parasites recorded per population in the introduced range, and their relationships according to linear regression (species: $\mathrm{R}^{2}=0.08, \mathrm{~F}_{1,4}=0.33, P>0.05$ ); genus: $\mathrm{R}^{2}=0.38$, $\left.\mathrm{F}_{1,4}=2.45, P>0.05\right)$. Open circles are species data, filled circles are genus data, solid lines represent fitted relationships (linear regression) for the species level data and the dotted line for genus level data, and dashed lines represent the null hypothesis that there are equal numbers of parasites per population between the native ranges and the introduced range species per population between the native and nonnative fishes using linear regression revealed that the gradient of the regression line was not significantly different to zero $(b=0.51, P=0.51)$ and $1.0(95 \%$ confidence intervals: -2.56 to 3.58 ) (Fig. 2), thus the null hypothesis was not rejected. There were also no significant differences in the number of internal, external and generalist parasites between the groups (Mann-Whitney U Test, $P>0.05$ in all cases). Too few specialist parasites were present in data to warrant their testing.

\section{Discussion}

The study outputs suggested when the non-native fishes were introduced into England Wales, they had undergone aspects of enemy release as only $8.5 \%$ of their native parasite fauna remained. Of those that had been introduced with the fish, the majority most were members of the Monogenea class of parasites. The relatively high host specificity of these parasites has so far limited disease risks to native fish populations (e.g. Hockley et al. 2011; Reading et al. 2011). However, examples of serious disease outbreaks following the translocation of monogenean parasites, such as Gyrodactylus salaris (Bauer et al. 2002; Bakke et al. 2007), highlights the importance of continued monitoring and prompt risk assessment to inform management (Williams et al. 2013).

There was no evidence that parasite spillover had occurred in any of the studied fish communities in the introduced range, with no recordings of the introduced parasites in the sympatric native fishes. Whilst there were seven parasites recorded in both the non-native fish and sympatric native fish communities, these were all generalist parasites native to England and Wales that had been acquired by the non-native fish. This does indicate that there was potentially some biotic resistance against these fishes (Mitchell and Power 2003). In the absence of parasite prevalence and abundance data, however, it could not be assessed whether these infections were likely to be having sufficient sub-lethal consequences in the non-native fish to prevent their long-term survival and establishment.

In general, the loss of their natural parasite fauna is often used as an explanatory variable in the invasion success of many non-native species (e.g. MacLeod et al. 2010; Mitchell and Power 2003; Ross et al. 2010). 
Table 2 Number of studies, and species and genera of parasites recorded in the non-native fishes in their native range, the total number of parasites recorded in these fishes in

\begin{tabular}{|c|c|c|c|c|c|c|c|c|c|}
\hline \multirow[t]{2}{*}{ Species } & \multirow[t]{2}{*}{ Range } & \multirow[t]{2}{*}{ Studies } & \multirow[t]{2}{*}{ Genera } & \multirow[t]{2}{*}{ Species } & \multicolumn{4}{|c|}{ Parasite species characteristics (\%) } & \multirow[t]{2}{*}{ References } \\
\hline & & & & & Internal & External & Specialist & Generalist & \\
\hline \multirow[t]{2}{*}{ Silurus glanis } & Native & 20 & 41 & 54 & 72 & 28 & 26 & 74 & $1-8$ \\
\hline & Introduced & 6 & 7 & 7 & 57 & 43 & 14 & 86 & This study \\
\hline \multirow[t]{2}{*}{ Lepomis gibbosus } & Native & 10 & 25 & 34 & 33 & 67 & 17 & 83 & $9-19$ \\
\hline & Introduced & 1 & 7 & 7 & 57 & 43 & 0 & 100 & 20 \\
\hline \multirow[t]{2}{*}{ Pseudorasbora parva } & Native & 10 & 13 & 13 & 54 & 31 & 8 & 92 & $21-22$ \\
\hline & Introduced & 4 & 2 & 2 & 100 & 0 & 0 & 100 & This study \\
\hline \multirow[t]{2}{*}{ Leucaspius delineatus } & Native & 12 & 9 & 11 & 54 & 46 & 18 & 82 & $23-28$ \\
\hline & Introduced & 1 & 6 & 6 & 66 & 34 & 0 & 100 & 29 \\
\hline \multirow[t]{2}{*}{ Ameiurus melas } & Native & 25 & 12 & 15 & 80 & 20 & 20 & 80 & $30-40$ \\
\hline & Introduced & 1 & 1 & 2 & 0 & 100 & 50 & 50 & This study \\
\hline \multirow[t]{2}{*}{ Rhodeus amarus } & Native & 16 & 33 & 42 & 45 & 55 & 10 & 90 & 41 \\
\hline & Introduced & 4 & 10 & 11 & 45 & 55 & 0 & 100 & This study \\
\hline \multirow[t]{2}{*}{ Pimephales promelas } & Native & 13 & 14 & 19 & 42 & 58 & 11 & 89 & $42-50$ \\
\hline & Introduced & 1 & 1 & 1 & 0 & 100 & 0 & 100 & This study \\
\hline
\end{tabular}

References as per Table 1

Table 3 Comparison of the numbers of parasite species of the non-native and sympatric fish present in fish communities in the UK, where N: native fish community, NN non-native fish
England Wales ('Introduced'), and the characteristics of the parasite species (site of attachment and host specificity)

\begin{tabular}{|c|c|c|c|c|c|c|c|c|}
\hline \multirow[t]{2}{*}{ Species } & \multirow{2}{*}{$\begin{array}{l}\text { Fish communities } \\
\text { studied }(n)\end{array}$} & \multirow{2}{*}{$\begin{array}{l}\text { Species } \\
\text { group }\end{array}$} & \multirow[t]{2}{*}{ Fish species } & \multirow{2}{*}{$\begin{array}{l}\text { Parasite species } \\
\text { recorded }(n)\end{array}$} & \multicolumn{4}{|c|}{ Parasite species characteristics $(\%)$} \\
\hline & & & & & Internal & External & Specialist & Generalist \\
\hline \multirow[t]{2}{*}{ Silurus glanis } & 3 & $\mathrm{~N}$ & $1-13$ & 17 & 29 & 71 & 0 & 100 \\
\hline & & $\mathrm{NN}$ & & 6 & 66 & 34 & 17 & 83 \\
\hline \multirow{2}{*}{$\begin{array}{l}\text { Lepomis } \\
\text { gibbosus }\end{array}$} & 1 & $\mathrm{~N}$ & $1,9,13$ & 3 & 0 & 100 & 0 & 100 \\
\hline & & $\mathrm{NN}$ & & 7 & 57 & 43 & 0 & 100 \\
\hline \multirow{2}{*}{$\begin{array}{l}\text { Pseudorasbora } \\
\text { parva }\end{array}$} & 2 & $\mathrm{~N}$ & $1,9,14$ & 5 & 42 & 58 & 0 & 100 \\
\hline & & $\mathrm{NN}$ & & 2 & 100 & 0 & 0 & 100 \\
\hline \multirow[t]{2}{*}{ Ameiurus melas } & 1 & $\mathrm{~N}$ & $2,3,9$ & 7 & 29 & 71 & 0 & 100 \\
\hline & & $\mathrm{NN}$ & & 2 & 0 & 100 & 50 & 50 \\
\hline \multirow[t]{2}{*}{$\begin{array}{l}\text { Rhodeus } \\
\text { amarus }\end{array}$} & 3 & $\mathrm{~N}$ & $\begin{array}{c}3,6,9,12 \\
13,15\end{array}$ & 26 & 53 & 47 & 0 & 100 \\
\hline & & $\mathrm{NN}$ & & 11 & 45 & 55 & 0 & 100 \\
\hline
\end{tabular}

1 Scardinius erythropthalmus; 2 Cyprinus carpio; 3 Perca fluviatilis; 4 Barbus barbus; 5 Anguilla anguilla; 6 Abramis Brama; 7 Squalius cephalus; 8 Leuciscus leuciscus; 9 Rutilus rutilus; 10 Tinca tinca; 11 Carassius carassius; 12 Esox lucius; 13 Gobio gobio; 14 Gasterosteus aculeatus; 15 Gymnocephalus cernus 


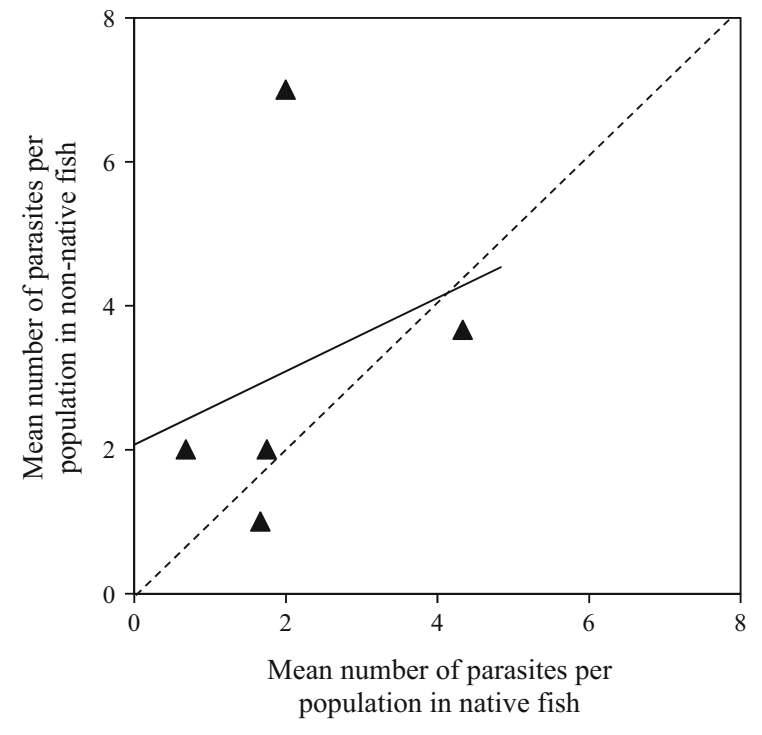

Fig. 2 Comparison of the mean number of parasite species per population of the native and non-native fish when in sympatry in the introduced range, where non-native fish were $S$. glanis, L. gibbosus, $P$. parva, A. melas and $R$. amarus. The solid line represents the fitted relationship for data (linear regression; and their relationships according to linear regression $\left(\mathrm{R}^{2}=0.51\right.$, $\left.\mathrm{F}_{1,3}=0.28, P>0.05\right)$ and the dashed line represents the null hypothesis that there are equal numbers of parasites per population in the non-native and native fish

In evaluating enemy release, it is important to understand why reductions in parasite fauna are occurring and why some parasites do manage to survive the introduction process. Here, some (but not all) of the parasites that survived the introduction process into England and Wales were monogenean parasites with direct lifecycles with no intermediate hosts (JimenezGarcia et al. 2001). The persistence of these parasites in the introduced range was likely to have been assisted by their simple lifecycle, providing there were sufficient numbers of hosts available. Indeed, MacLoed et al. (2010) concluded that life cycle complexity and transmission efficiency were the more likely causes of introduced parasites failing to establish in the new range rather than the parasites being lost during the introduction process. Nevertheless, there are a number of studies that do not support the ERH (e.g. Ramalho et al. 2009; Lacardo et al. 2013; Poulin and Mouillot 2003). For example, Lacerda et al. (2013) suggested that as important as the number and diversity of parasites being present in the non-native species are the effects of the parasites on the hosts, with parasite prevalence and abundance often being greater in the introduced range. As this aspect could not be assessed here due to the absence of data on parasite prevalence and abundance, it is an aspect of the parasite fauna of non-native fish in England and Wales that should be studied subsequently.

Comparisons between the parasite fauna of the native and non-native fish in the study provided no evidence of PSO, perhaps due to the low number of introduced parasites generally that made this an unlikely process. Nevertheless, other studies suggest it remains an important process due to the potential for damaging outcomes occurring in infected native hosts (e.g. Taraschewski 2006; Prenter et al. 2004; Liu and Stiling 2006). In some cases, spill-over occurs at relatively high levels, as the majority of introduced parasites spill over into native hosts (Jimenez-Garcia 2001), such as the helminth parasite fauna from the non-native lizard, Tupinambis merianae, into the native reptile fauna (Ramalho et al. 2009). By contrast, there was greater evidence in our study of native parasites infecting the non-native fishes and this process is generally well reported (e.g. JimenezGarcia 2001; Krakau et al. 2006). For example, the two salmonid fish species Oncorhynchus mykiss and Salmo trutta accumulate parasite communities in their introduced ranges at similar abundances to their host range, negating any beneficial consequences they might have gained from enemy release (Poulin and Mouillot 2003). In our study, the acquired parasites resulted in similar mean parasite numbers per population in England and Wales as the native range of the fishes. These mean number of parasite species per population were also not significantly different to those in the sympatric fishes present in the invaded communities of England and Wales. Some caution in these conclusions is warranted due to the relatively low numbers of populations that could be studied in England and Wales that limited the power of statistical tests. The observed patterns in the data, however, were also very supportive of these conclusions and so they have validity.

The importance of parasite dynamics in the establishment and invasion processes of non-native species is through the advantages provided to those species in terms of their traits and fitness when their parasite fauna is reduced (Torchin et al. 2003). It can enable increased resource allocation for somatic growth and reproduction, and increase immune responses to infections of native parasites (Joshi and Vrieling 
2005). In combination, these serve to increase the probability of the establishment and invasion, thus subsequently altering interactions in the host fish community (Keane and Crawley 2002). Whilst fish introductions in England Wales are routinely screened for certain 'notifiable' diseases before release (at least where introduction is intentional and approved; Davies et al. 2013), there is arguably a requirement for increased parasite screening for introductions of non-native fish. However, with differing legislative, economic and political drivers, managing the introduction and spread of non-native pathogens represents a complex global challenge (Williams et al. 2013). Although we found few examples of non-native fish pathogens being imported directly on seven nonnative fishes, Phillips et al. (2010) found that, whilst initially an invasive species may experience parasite release, those that do remain-even in low abundance-might re-establish, having consequences on both the non-native host and the wider fish community. Moreover, the detection tools used in screening are important. Here, we considered only those parasites that could be detected through routine health screening which included low and high-power microscopy (Hoole et al. 2001). However, these are unlikely to detect intra-cellular pathogens such as Sphaerothecum destruens that is hosted by P. parva (Gozlan et al. 2005). This pathogen has proved difficult to detect in wild populations, due to its size and the absence of disease or gross tissue damage, but is now increasingly being detected as molecular methodologies improve, with this resulting in the recent detection of its presence and distribution in countries such as the Netherlands (Spikmans et al. 2013). This is important, given that this pathogen is associated with potentially substantial mortality rates in salmonid and cyprinid fishes (Andreou et al. 2012). In addition, it suggests that whilst the recorded numbers of non-native parasites were low in this study, with negligible spill-over, this might not cover all pathogens being hosted by the non-native fishes. Others might have been introduced but were not detected using the methodologies employed.

In summary, it was revealed that the introduction of these seven non-native fishes in England and Wales was not concomitant with the introduction of a high diversity of non-native parasites. Whilst there was some evidence of native parasites infecting these nonnative fishes (and so, potentially, leading to parasite spill-back), there was negligible evidence of parasite spill-over from the non-native to the native fishes. Whilst some caution is needed on this given the case study of $S$. destruens in $P$. parva, overall it suggests that enemy release could provide some partial explanations for the survival and establishment success of some non-native fishes in England and Wales.

Acknowledgments The study was supported by the Natural Environment Research Council (NERC research Grant Reference Number NE/J016675/1). The views expressed are those of the authors and not their parent organisation.

Open Access This article is distributed under the terms of the Creative Commons Attribution 4.0 International License (http:// creativecommons.org/licenses/by/4.0/), which permits unrestricted use, distribution, and reproduction in any medium, provided you give appropriate credit to the original author(s) and the source, provide a link to the Creative Commons license, and indicate if changes were made.

\section{References}

Adrović A, Žujo D, Skenderović I, Marković G and Bajrić A (2011) Distribution of posthodiplostomum cuticola (digenea) metacercariae in cyprinids of the Modrac reservoir. V international conference "Aquaculture and Fishery" conference proceedings, pp 319-324

Aho JM, Gibbons JW and Esch GW (1976) Relationship between thermal loading and parasitism in the mosquitofish. In: Esch GW, McFarlane RW (eds) Thermal ecology II. ERDA Symp. Ser. (CONF-750425), pp 213-218. National Technical Information Center, Oak Ridge, TN

Aliabadi BW, Juliano SA (2002) Escape from gregarine parasites affects the competitive interactions of an invasive mosquito. Biol Invasions 4:283-297

Andreou D, Arkush KD, Guégan JF, Gozlan RE (2012) Introduced pathogens and native freshwater biodiversity: a case study of Sphaerothecum destruens. PLoS ONE 7:e36998

Andrews C, Chubb JC (1984) Helminth parasites from Yorkshire fishes. Bull Eur Assoc Fish Pathol 4:22-23

Bakke TA, Cable J, Harris PD (2007) The biology of gyrodactylid monogeneans: the "Russian-doll killers". Adv Parasit 64:161-460

Bangham RV (1941) Parasites from fish of Buckeye Lake, Ohio. Ohio J Sci 41:441-448

Barzegar M, Jalali B (2010) Crustacean parasites of fresh and brackish (Caspian Sea) water fishes of Iran. J Agric Sci Technol 11:161-171

Bauer ON, Pugachev ON, Voronin VN (2002) Study of parasites and diseases of sturgeons in Russia: a review. J Appl Ichthyol 18:420-429

Beyer K, Kochanowska D, Longshaw M, Feist SW, Gozlan RE (2005) A potential role for invasive sunbleak in the further dissemination of a non-native parasite. J Fish Biol 67:1730-1733 
Britton JR (2013) Introduced parasites in food-webs: new species, shifting structures? Trends Ecol Evol 28:93-99

Britton JR, Cucherousset J, Davies GD, Godard MJ, Copp GH (2010) Non-native fishes and climate change: predicting species responses to warming temperatures in a temperate region. Freshw Biol 55:1130-1141

Cone DK, Anderson RC (1977a) Myxosporidan parasites for pumpkinseed (Lepomis gibbosus L.) from Ontario. J Parasitol 63:657-666

Cone DK, Anderson RC (1977b) Parasites of pumpkinseed (Lepomis gibbosus L.) from Ryan Lake, Algonquin Park, Ontario. Can J Zool 55:1410-1423

Copp GH, Britton JR, Cucherousset J, Garcia-Berthou E, Kirk R, Peeler E, Stakenas S (2009) Voracious invader or benign feline? A review of the environmental biology of European catfish Silurus glanis in its native and introduced ranges. Fish Fish 10:252-282

Dávidová M, Ondračková M, Jurajda P, Gelnar M (2008) Parasite assemblages of European bitterling (Rhodeusamarus), composition and effects of habitat type and host body size. Parasitol Res 102:1001-1011

Davies GD, Gozlan RE, Britton JR (2013) Can accidental introductions of non-native species be prevented by fish stocking audits? Aquat Conserv 23:366-373

Davydov ON, Kyrovskaya LY, Bazeev RY (2003) On distribution of fish ligulosis in the Kiev reservoir. Hydrobiol J 39:55-60

Dronen NO Jr, Underwood HT (1980) Pseudomagnivitellinum ictalurum gen. et sp. n. (Digenea: Macroderoididae) from the black bullhead of south-central Texas. Proc Helminth Soc Washington 47:52-54

Esch GW (1971) Impact of ecological succession on the parasite fauna in centrarchids from oligotrophic and eutrophic ecosystems. Am Midl Nat 86:160-168

Fausch KD (2007) Introduction, establishment and effects of non-native salmonids: considering the risk of rainbow trout invasion in the United Kingdom. J Fish Biol 71:1-32

Galaktionov KV (1980) The life cycle of Mesostephanus appendiculatus (Ciurea, 1916) Lutz, 1935 nec Martin, 1961. Vestnik Leningradskogo Universiteta. Biologiya 21:27-34

Gozlan RE, St-Hilaire S, Feist SW, Martin P, Kents ML (2005) Disease threat to European fish. Nature 435:1046

Gozlan RE, Andreou D, Asaeda T et al (2010a) Pan-continental invasion of Pseudorasbora parva: towards a better understanding of freshwater fish invasions. Fish Fish 11:315-340

Gozlan RE, Britton JR, Cowx IG et al (2010b) Current knowledge on non-native freshwater fish introductions. J Fish Biol 76:751-786

Grupcheva GI, Nedeva IL (2000) Parasite fauna of the crucian carp (Carassius auratus gibelio Bloch.) in the Zrebchevo reservoir (Bulgaria). Acta Zool Bulg 51:115-122

Hanek G, Fernando CH (1978) Spatial distribution of gill parasites of Lepomis gibbosus (L.) and Ambloplites rupestris (Raf.). Can J Zool 56:1235-1240

Hatcher MJ, Dunn AM (2011) Parasites in ecological communities. Cambridge University Press, Cambridge

Held JW, Peterka JJ (1974) Age, growth, and food habits of the fathead minnow, Pimephales promelas, in North Dakota saline lakes. Trans Am Fish Soc 103:743-756
Hewlett NR et al (2009) The role of management practises in fish mortality incidents in recreational lake fisheries in the introduced range. Fish Man Ecol 16:248-254

Hockley FA, Williams CF, Reading AJ, Taylor NGH, Cable J (2011) Parasite fauna of introduced pumpkinseed fish Lepomis gibbosus: first British record of Onchocleidus dispar (Monogenea). Dis Aquat Organ 97:65

Hoole D, Bucke D, Burgess P, Wellby I (2001) Diseases of Carp and Other Cyprinid Fishes. Blackwell, Oxford

Hudson PL, Bowen CA II (2009) First record of Neoergasilus japonicus (Poecilostomatoida: Ergasilidae), a parasitic copepod new to the Laurentian Great Lakes. J Parasitol 88:657-663

Hugghins EJ (1954) Life history of a strigeid trematode, Hysteromorpha triloba (Rudolphi, 1819) Lutz, 1931. I. Egg and miracidium. Trans Am Microsc Soc 73:1-15

Hulme PE et al (2009) Will the threat of biological invasions unite the European Union? Science 324:40-41

Jiménez-García MI, Vidal-Martínez VM, López-Jiménez S (2001) Monogeneans in introduced and native cichlids in México: evidence for transfer. J Parasitol 87:907-909

Joshi J, Vrieling K (2005) The enemy release and EICA hypothesis revisited: incorporating the fundamental difference between specialist and generalist herbivores. Ecol Lett 8:704-714

Keane RM, Crawley MJ (2002) Exotic plant invasions and the enemy release hypothesis. Trends Ecol Evol 17:164-169

Keith SA, Newton AC, Morecroft MD, Bealey CE, Bullock JM (2009) Taxonomic homogenization of woodland plant communities over 70 years. Proc R Soc B 276:3539-3544

Kelly DW, Paterson RA, Townsend CR, Poulin R, Tompkins DM (2009) Parasite spillback: a neglected concept in invasion ecology? Ecology 90:2047-2056

Kirjušina M, Vismanis K (2007) Checklist of the parasites of fishes of Latvia. Fisheries technical paper. 369

Knipes AK, Janovy J Jr (2009) Community structure and seasonal dynamics of Dactylogyrus spp. (Monogenea) on the fathead minnow (Pimephales promelas) from the Salt Valley watershed, Lancaster County, Nebraska. J Parasitol 95:1295-1305

Krakau M, Thieltges DW, Reise K (2006) Native parasites adopt introduced bivalves of the North Sea. Biol Invasions 8:919-925

Kvach Y, Stepien CA (2008) Metazoan parasites of introduced Round and Tubenose Gobies in the Great Lakes: support for the "Enemy Release Hypothesis". J Great Lakes Res 34:23-35

Lacerda ACF, Takemoto RM, Poulin R, Pavanelli GC (2013) Parasites of the fish Cichla piquiti (Cichlidae) in native and invaded Brazilian basins: release not from the enemy, but from its effects. Parasitol Res 112:279-288

Lincicome DR, Van Cleave HJ (1949) Distribution of Leptorhynchoides thecatus, a common acanthocephalan parasitic in fishes. Am Midl Nat 41:421-431

Liu H, Stiling P (2006) Testing the enemy release hypothesis: a review and meta-analysis. Biol Invasions 8:1535-1545

Luque JL, Poulin RL (2007) Metazoan parasite species richness in Neotropical fishes: hotspots and the geography of biodiversity. Parasitology 134:865-878

MacLeod CJ, Paterson AM, Tompkins DM, Duncan R (2010) Parasites lost-do invaders miss the boat or drown on arrival? Ecol Lett 13:516-527 
Mancheva K, Karaivanova E, Atanasov G, Stojanovski S, Nedeva I (2009) Analysis of the influence of the host body size on morphometrical characteristics of Ancylodiscoides siluri and Ancylodiscoides vistulensis. Biotechnol Biotechnol Equip 23:735-741

Marr SR et al (2008) Parasite loss and introduced species: a comparison of the parasites of the Puerto Rican tree frog, (Eleutherodactylus coqui), in its native and introduced ranges. Biol Invasions 10:1289-1298

McAllister CT, Bursey CR (2011) Corallotaenia parva (Cestoidea: Proteocephalidae) from the Black Bullhead, Ameiurus melas (Siluriformes: Ictaluridae) in Southeastern Oklahoma. Proc Okla Acad Sci 91:29-30

McDowell MA, Ferdig MT, Janovy J (1992) Dynamics of the Parasite Assemblage of Pimephales promelas in Nebraska. J Parasitol 78:830-836

Merritt SV, Pratt I (1964) The life history of Neoechinorhynchus rutili and its development in the intermediate host (Acanthocephala: Neoechinorhynchidae). J Parasitol 50:394-400

Mitchell CE, Power AG (2003) Release of invasive plants from fungal and viral pathogens. Nature 421:625-627

Mitchell AJ, Smith CE, Hoffman GL (1982) Pathogenicity and histopathology of an unusually intense infection of white grubs (Posthodiplostomum m. minimum) in the fathead minnow (Pimephales promelas). J Wildl Dis 18:51-57

Mizelle JD, Cronin JP (1943) Studies on monogenetic trematodes X. Gill parasites from Reelfoot lake Fishes. Am Mid Nat 30:196-222

Molnar K (1976) To the knowledge of the Monogenea-fauna in Hungary. Parasit Hung 9:31-33

Osborn HL (1911) On the distribution and mode of occurrence in the United States and Canada of Clinostomum marginatum, a trematode parasitic in fish, frogs and birds. Biol Bull 20:350-366

Pazooki J, Masoumian M (2012) Synopsis of the parasites in Iranian freshwater fishes, Iran. J Fish Sci 11:570-589

Phillips BL, Kelehear C, Pizzatto L, Brown GP, Barton D, Shine R (2010) Parasites and pathogens lag behind their host during periods of host range-advance. Ecology 91:872-881

Piasecki W, Falandysz M (1994) Preliminary survey on parasite fauna of pumpkinseed sunfish, Lepomis gibbosus (Linnaeus, 1758) (Pisces, Teleostei, Centrarchidae), from warm-water discharge canal of the" Pomorzany" power plant in Szczecin, Poland. Acta Ichthyol Piscat 24:87-100

Poulin R, Mouillot D (2003) Host introductions and the geography of parasite taxonomic diversity. J Biogeogr 30:837-845

Prenter J, MacNeil C, Dick JTA, Dunn AM (2004) Roles of parasites in animal invasions. Trends Ecol Evol 19:385-390

Pysek P et al (2010) Disentangling the role of environmental and human pressures on biological invasions across Europe. Proc Nat Acad Sci USA 107:12157-12162

Radabaugh DC (1980) Changes in minnow, Pimephales promelas Rafinesque, schooling behaviour associated with infections of brain encysted larvae of the fluke, Ornithodiplostomum ptychocheilus. J Fish Biol 16:621-628

Ramalho ACO, Schwartz HO, Péres AK Jr (2009) Helminths from an introduced species Tupinambis merianae, and two endemic species (Trachylepis atlantica and Amphisbaena ridleyi) from Fernando de Noronha Archipelago, Brazil. J Parasitol 95:1026-1028
Reading AJ, Britton JR, Davies GD, Shinn AP, Williams CF (2011) Introduction and spread of non-native parasites with Silurus glanis L. (Teleostei: Siluridae) in UK fisheries. J Helminthol 1:1-4

Rogers WA (1969) Ergasiluscyprinaceus sp. n. (Copepoda: Cyclopoida) from Cyprinid Fishes of Alabama, with notes on Its Biology and Pathology. J Parasitol 55:443-446

Ross JL et al (2010) The role of parasite release in invasion of the USA by European slugs. Biol Invasions 12:603-610

Rye LA, Baker MR (1984) Hysterothylacium analarum n. sp. (Nematoda: Anisakidae) from pumpkinseed, Lepomis gibbosus (Linnaeus), in southern Ontario. Can J Zool 62:2307-2312

Samuel N, Nickol BB, Mayes M (1976) Acanthocephala of Nebraska fishes. Am Mid Nat 96:391-406

Sattari M, Shafii S, Roohi JD, Biria HA, Bekhsat N (2002) Occurrence and intensity of Eustrongylides excisus (L.) (Nematoda: Dioctophymidae) from some bony fish species in Caspian Sea and its basin, Iran. J Facf Vet Med Univ Tehran 57:37-41

Seamster A (1948) Gill parasites from Louisiana fishes with a description of Urocleidus wadei n. sp. Am Midl Nat 39:165-168

Skenderovic I, Zujo D, Adrovic A, Markovic G (2011) Tremato de fauna of some fish species in the river spreča. International Conf Aquac Fish Proc 5:294-301

Soylu E (2005) Metazoan parasites of catfish (Silurus glanis, Linnaeus, 1758) from Durusu (Terkos) Lake. J Black Sea/ Mediterr Environ 11:225-237

Spikmans F, van Tongeren T, van Alen TA, van der Velde G, den Camp HJ (2013) High prevalence of the parasite Sphaerothecum destruens in the invasive topmouth gudgeon Pseudorasbora parva in the Netherlands, a potential threat to native freshwater fish. Aquat Invasions 8:355-360

Steelman GM (1938) A Description of Phyllodistomum caudatum n. sp. Am Midl Nat 19:613-616

Taraschewski H (2006) Hosts and parasites as aliens. J Helminthol 80:99-128

Taylor LH, Hall BK, Miyake T, Cone DK (1994) Ectopic ossicles associated with metacercariae of Apophallus brevis (Trematoda) in yellow perch, Perca flavescens (Teleostei): development and identification of hone and chondroid bone. Anat Embryol 190:29-46

Tkach VV, Mills AM (2011) Alloglossidium fonti sp. nov. (Digenea, Macroderoididae) from black bullheads in Minnesota with molecular differentiation from congeners and resurrection of Alloglossidium kenti. Acta Parasitol 56:154-162

Tompkins DM et al (2001) Wildlife diseases: from individuals to ecosystems. J Anim Ecol 80:19-38

Torchin ME, Mitchell CE (2004) Parasites, pathogens and invasions by plants and animals. Front Ecol Environ 2:183-190

Torchin ME et al (2003) Introduced species and their missing parasites. Nature 421:628-630

Van Cleave HJ (1921) Notes on two genera of ectoparasitic trematodes from fresh-water fishes. J Parasitol 8:33-39

Voth DR, Larson OR (1968) Metazoan parasites of some fishes from Goose River, North Dakota. Am Mid Nat 79:216-224

Wallace FG (1935) A Morphological and Biological Study of the Trematode, Sellacotyle mustelae ng, n. sp. J Parasitol 21:143-164 
Williams CF, Turnbull J, Britton JR (2013) A risk assessment for managing non-native parasite in inland fisheries. Biol Invasions 15:1273-1286

Wilson KA, Ronald K (1967) Parasite fauna of the sea lamprey (Petromyzon marinus von Linné) in the Great Lakes region. Can J Zool 45:1083-1092

Žd'árská Z, Nebesáŕová J (2005) Transmission electron microscopy of the scolex and neck microtriches of
Silurotaenia siluri (Batsch, 1786) (Cestoda: Proteocephalidea). Parasit Res 97:98-102

Zhang R, Gao S, Geng Y, Huang D, Yu L, Zhan S, Fu Y (2007) Epidemiological study on Clonorchis sinensis infection in Shenzhen area of Zhujiang delta in China. Parasit Res 101:179-183 